\title{
Profile of Children with Congenital Heart Disease and Upper Respiratory Tract Infection in Dr. Soetomo General Hospital Surabaya Period March 2018
}

\author{
Nabila Izzati ${ }^{1}$, Mahrus A Rahman ${ }^{2}$, Ni Wajan Thirthaningsih ${ }^{3}$
}

\author{
${ }^{1}$ Faculty of Medicine, Universitas Airlangga, Surabaya, Indonesia. \\ 2 Cardiology Division, Department of Paediatric, Faculty of Medicine, Universitas Airlangga - Dr. Soetomo General Hospital, \\ Surabaya, Indonesia. \\ 3 Department of Anatomy and Histology, Faculty of Medicine, Universitas Airlangga, Surabaya, Indonesia.
}

\begin{abstract}
A B S T R A C T
Introduction: Congenital Heart Disease (CHD) is the leading cause of death in the first year of life. One of the manifestations of $\mathrm{CHD}$ is upper respiratory infection (URI). In Indonesia, 90\% of the acute respiratory infection is URI and it becomes the most common reason for children to go to emergency center. The aim of this study is to describe the profile of children with congenital heart disease and upper respiratory tract infection (URTI) in Dr. Soetomo General Hospital, Surabaya, based on sex, age, immunization status, social-economic status, and type of CHD.
\end{abstract}

Methods: This descriptive study was done by collecting data using medical records and questionnaires from March $1^{\text {st }}$ to $31^{\text {st }} 2018$.

Results: Total number of the sample was 46 patients; 18 (39.1\%) of them were male and $28(60.9 \%)$ were female, with male to female ratio was $1: 1.6$. The most common age group $(69.6 \%)$ was toddler (0-5 years old). The most common type of CHD was acyanotic $(89.1 \%)$.

Conclusion: Female patients had more (80\%) severe URI than male patients. Patients with severe URI only occur in toddlers. Interestingly, $60 \%$ of patients with severe URI had complete immunization. Patients with severe URI had parents with moderate $(60 \%)$ and low income $(40 \%)$. There were $100 \%$ of patients with severe URI who had acyanotic CHD.

\footnotetext{
*Correspondence: mahrus_rahman@yahoo.com

JUXTA: Jurnal IImiah Mahasiswa Kedokteran Universitas Airlangga

p-ISSN: 1907-3623; e-ISSN: 2684-9453
}

DOI: 10.20473/juxta.V10I22019.57-59

Open access under Creative Commons Attribution-ShareAlike 4.0 International License (CC-BY-SA)

\author{
ARTICLE INFO \\ Article history: \\ Received 05 August 2019 \\ Received in revised form 15 \\ August 2019 \\ Accepted 21 August 2019 \\ Keywords: \\ Congenital heart disease, \\ Upper respiratory tract infection, \\ Cyanotic, \\ Acyanotic, \\ Immunization.
}




\section{Introduction}

Congenital heart disease (CHD) is abnormal defect of the heart or large blood vessel which is happening during developing process of the embryo ${ }^{1}$. The defect varies from minor ventricle septum defect which only needs a month of treatment until more complex ventricle abnormalities which need emergency treatment ${ }^{2}$. CHD is the leading cause of death in the first year of life ${ }^{3}$. The incidence of $\mathrm{CHD}$ varies from 4/1000 until 50/1000 live birth ${ }^{1}$.

CHD becomes risk factor of some diseases, one of them is upper respiratory tract infection (URTI). Patients with CHD have big risk to get vascular respiratory problem. Children with CHD have heavy blood flow to the lungs which leads to enlargement of lung tissue volume. The air volume of left lung will proportionally be smaller than the right lung caused by the pressure from the heart ${ }^{4}$. Children with $\mathrm{CHD}$ and having respiratory infection will recover longer than normal ones because heart disease worsen that condition ${ }^{5}$.

URTI can be caused by viruses, such as Adenovirus and Rhinovirus ${ }^{6}$. URTI included in most frequent infection diseases in children with six to eight episodes in a year and it's categorized into the most frequent reason for children to go to emergency room 7 .

Profile of children with CHD and URTI is still not completely known by many people. Therefore, the researcher was interested in conducting this research to get to know more about profile of children with CHD and URTI in Dr. Soetomo General Hospital, Surabaya.

\section{Methods}

This study used a descriptive research design conducted at Outpatient Clinic of Dr. Seotomo General Hospital, Surabaya and carried out from March $1^{\text {st }}$ to $31^{\text {th }}$ 2018. The total number of subjects were 46 patients. The population in this study were all children with $\mathrm{CHD}$ at Outpatient Clinic of Dr. Seotomo General Hospital, Surabaya. The subjects in this study were children with CHD and URTI at Outpatient Clinic of Dr. Seotomo General Hospital, Surabaya in the period of March $1^{\text {st }}$ to $31^{\text {th }} 2018$ below the age of 18 years. This study used secondary data in the form of medical records. Besides, this study also used questionnaires for completing data. Research had received ethical approval from Research and Development Department of Dr. Seotomo General Hospital, Surabaya with the number of ethics permit 0023/KEPK/II/2018. Data obtained from medical records were processed using Microsoft Excel 2016, then presented in table form.

\section{Results}

In this study, a total subject is 46 patients of children with CHD and URTI.

Table 1. Characteristic of Children with CHD and URTI in Dr. Soetomo General Hospital, Surabaya in the Period of March $1^{\text {st }}$ to $31^{\text {th }} 2018$.

\begin{tabular}{|c|c|c|}
\hline Characteristic & $\begin{array}{c}\text { Frequency } \\
(n=46)\end{array}$ & $\%$ \\
\hline \multicolumn{3}{|l|}{ Gender } \\
\hline Male & 18 & 39.1 \\
\hline $\begin{array}{l}\text { Female } \\
\text { Age Category }\end{array}$ & 28 & 60.9 \\
\hline Toddler $(0-5$ years $)$ & 32 & 69.6 \\
\hline Children (5-11 years) & 8 & 17.4 \\
\hline Early teenager (12-16 years) & 6 & 13 \\
\hline Late teenager (17-25 years) & 0 & 0 \\
\hline \multicolumn{3}{|l|}{ Immunization record } \\
\hline Completed & 33 & 72 \\
\hline Not completed & 13 & 28 \\
\hline \multicolumn{3}{|l|}{ Parents' income/month } \\
\hline Low $(<$ Rp.500.000,00) & 6 & 13 \\
\hline $\begin{array}{l}\text { Moderate (Rp. } 1.500 .000,00 \text { to } \\
\text { Rp.2.500.000.00) }\end{array}$ & 16 & 34.8 \\
\hline $\begin{array}{l}\text { High (Rp.2.500.000,00 to } \\
\text { Rp.3.500.000,00) }\end{array}$ & 17 & 37 \\
\hline $\begin{array}{l}\text { Very high (> Rp.3.500.000,00) } \\
\text { Type of CHD }\end{array}$ & 7 & 15.2 \\
\hline Cyanotic & 5 & 10.9 \\
\hline Acyanotic & 41 & 89.1 \\
\hline
\end{tabular}

Table 1 shows that the distribution of female patients is larger than male patients with ratio 1:1.6, with the largest distribution of patients is in the age group of $0-5$ years (69.6\%). Most patients with CHD and URTI have completed immunization record (72\%). Besides, there were $34.8 \%$ patients with moderate parent's income per month and most of the patients with URTI had acyanotic CHD (89.1\%).

Table 2. Distribution of Severity of URTI Based on Immunization Record.

\begin{tabular}{ccccccc}
\hline & \multicolumn{7}{c}{ Severity of URTI } \\
$\begin{array}{c}\text { Immunization } \\
\text { Record }\end{array}$ & \multicolumn{2}{c}{ Mild } & \multicolumn{3}{c}{ Moderate } & \multicolumn{2}{c}{ Severe } \\
& $\mathrm{f}$ & $\%$ & $\mathrm{~F}$ & $\%$ & $\mathrm{f}$ & $\%$ \\
\hline $\begin{array}{c}\text { Completed } \\
\text { Not }\end{array}$ & 15 & 83 & 19 & 70 & 3 & 60 \\
$\begin{array}{c}\text { completed } \\
\text { Total }\end{array}$ & 3 & 17 & 8 & 30 & 2 & 40 \\
& 18 & 100 & 27 & 100 & 5 & 100
\end{tabular}

Table 2 above shows that patients with all severity of URTI had completed immunization record. From five patients with severe URTI, three patients (60\%) had completed immunization record.

Table 3. Distribution of Severity of URTI Based on Parent's Income.

\begin{tabular}{ccccccc}
\hline & \multicolumn{7}{c}{ Severity of URTI } \\
Parent's income & \multicolumn{2}{c}{ Mild } & \multicolumn{3}{c}{ Moderate } & \multicolumn{2}{c}{ Severe } \\
& $\mathrm{f}$ & $\%$ & $\mathrm{f}$ & $\%$ & $\mathrm{f}$ & $\%$ \\
\hline Low & 2 & 13.3 & 2 & 7.7 & 2 & 40 \\
Moderate & 6 & 40 & 7 & 26.9 & 3 & 60 \\
High & 4 & 26.7 & 13 & 50 & 0 & 0 \\
Very High & 3 & 20 & 4 & 15,4 & 0 & 0 \\
Total & 15 & 100 & 26 & 100 & 5 & 100 \\
\hline
\end{tabular}


Table 3 shows that most patients with mild URTI had moderate parent's income $(40 \%)$, while patients with moderate URTI had high parent's income (50\%). Patients with severe URTI had moderate parent's income $(60 \%)$ with none of them had high or very high parent's income.

Table 4. Distribution of Severity of URTI Based on Type of CHD.

\begin{tabular}{|c|c|c|c|c|c|c|}
\hline \multirow{3}{*}{$\begin{array}{c}\text { Type of } \\
\text { CHD }\end{array}$} & \multicolumn{6}{|c|}{ Severity of URTI } \\
\hline & \multicolumn{2}{|c|}{ Mild } & \multicolumn{2}{|c|}{ Moderate } & \multicolumn{2}{|c|}{ Severe } \\
\hline & $f$ & $\%$ & $f$ & $\%$ & $f$ & $\%$ \\
\hline Cyanotic & 2 & 13.3 & 2 & 7.7 & 0 & 0 \\
\hline Acyanotic & 13 & 86.7 & 24 & 92.3 & 5 & 100 \\
\hline Total & 15 & 100 & 26 & 100 & 5 & 100 \\
\hline
\end{tabular}

Table 4 shows that most patients with all severity of URTI had acyanotic CHD. There were $86.7 \%$ patients with mild URTI had acyanotic CHD. There were $92.3 \%$ patients with moderate URTI and $100 \%$ patients with severe URTI had acyanotic CHD.

\section{Discussion}

In this research, the total number of patients who met the inclusion criteria was 46 people. There were 18 (39.1\%) male patients and $28(60.9 \%)$ female patients with a male to female ratio of $1: 1.6$. This is similar to a research conducted at Surabaya PHC Hospital which took sample of $\mathrm{CHD}$ patients and respiratory infections, the total number of female patients $(53.2 \%)$ was the highest number of all patients ${ }^{8}$. This is the opposite of Muhammad Habibi Syahidia's research which stated that there were more male patients with respiratory tract infections $(73.8 \%)$ than female patients $(72.1 \%)^{9}$.

Gender is considered to affect the severity of infection disease for toddler. In this study, female had more severe respiratory infections (80\%) than male. These results are in line with studies in mice on influenza viruses carried out by Molly A. Ingersoll in 2017 which stated that female sex had morbidity and mortality rates were higher than male sex. This is due to an increase in cytokines, such as Tumor Necrosis Factor (TNF) $-\alpha$ and C-C chemokine ligand 2 (CCL2) motifs in women ${ }^{10}$. However, in the study of Anak Agung Anom Sukamawa (2006), it was stated that gender is not a factor that influences the incidence of respiratory infections in children under five years old ${ }^{11}$.

The age group of the majority patients with CHD with URTI was toddler as many as $69.6 \%$. This result is similar to the study conducted by Rocky Wilar and J. M. Wantania which stated that 26 of 47 patients were toddlers ${ }^{5}$. According to Duppenthaler et al. (2014) and Boyce et al. (2000), children with CHD are susceptible to respiratory tract infections especially in their first year ${ }^{12,13}$. According to Brook (2012) and Cabalca (2004), this may be related to immune status and small airway size in younger children ${ }^{14}$, 15 .

In this study, $72 \%$ of CHD patients with URTI had a history of complete immunization according to age. This is similar to the research conducted in Puskesmas Kelurahan
Tebet Barat, DKI Jakarta which stated that 60 out of 104 patients with respiratory infections have a history of complete basic immunization ${ }^{9}$.

Immunization can stimulate the immunity so that the baby can be protected from several dangerous diseases. Immunization in children such as diphtheria, pertussis, and measles immunization can prevent deaths caused by respiratory infections. Children are encouraged to get complete immunization so that the progression of the disease will not become more severe ${ }^{16}$. However, in this study patients with mild, moderate, and severe respiratory tract infections had complete immunization. This is contrary to research conducted in the population of the United States which stated that annual infection immunization such as influenza immunization can alleviate the morbidity of URTI ${ }^{17}$. This difference can be caused by many other factors that can cause the severity of infection, such as nutritional status, low birth weight, and so on.

Apart from the above factors, there are some uniqueness in this study, specifically the income of the patients' parents is mostly classified as high income. The number of patients with severe infections is greater in patients with low parent's income $(40 \%)$ than patients with high parent's income (0\%). The same thing was also obtained from the study of Anak Agung Anom Sukamawa (2006) which stated that the risk for the occurrence of Acute Respiratory Infection (ARI) in children under five years old who had less income was 0.245 times greater than the families of children with high income. Parent's income can affect behavior related to hygiene and health ${ }^{11}$. For example, low-income parents tend not to seek immediate treatment if their child is sick so that the disease becomes more severe over time.

However, it is also possible if high-income parents have children with severe respiratory tract infections. This difference can be caused by other factors that play a role, such as low education levels.

Differences in exposure and susceptibility to infection are one mechanism that can be associated with social factors in shaping health status in individuals. Early exposure to infection will be an important factor in infectious diseases in children. Children with low family income will be more often exposed to infectious diseases, such as cigarette smoke, poor nutrition, stress, etc ${ }^{18}$. This will make the children exposed to antibodies earlier than children with high family income. Children with low family income can have better immunity due to exposure to previous infectious agents.

According to the research conducted at Karachi Hospital and Aga Khan University in October to December 20212, many high-income families received no notification of vaccination. This unconsciousness to visit health centers to get vaccinations is the most frequent reason to not getting vaccinations ${ }^{19}$. Children who have not received previous vaccinations will certainly be more vulnerable to disease, including infectious diseases.

In this study, the highest number of $\mathrm{CHD}$ patients in URTI was acyanotic PJB (89.1\%), followed by cyanotic PJB $(10.9 \%)$. This is similar to the study of Rocky Wilar and J. M. Wantania in 2006 which stated that acyanotic PJB 
patients were $61.7 \%$ while cyanotic PJB patients were $38.3 \%{ }^{9}$.

In this study, severe URTI only occurs in acyanotic CHD. Different results were obtained from research in Manado in 2006 which stated that the severity of respiratory tract infections in cyanotic CHD was higher, 15-16 times/year than acyanotic PJB, 9-10 times/year ${ }^{9}$. According to Keith L Moore (2014), acyanotic CHD causes pulmonary hypertension which leads to compression of the large bronchi by the left atrium or enlarged pulmonary artery, so that the lungs become hyperperfused and experience edema. In addition, the respiratory pathway becomes hypoplastic and there is impaired perfusion ventilation. The things above will cause airway mucosal damage and impaired immunity which will increase the risk of respiratory infections $^{20}$

\section{Conclusion}

Female patients had more ( $80 \%$ ) severe URI than male patients. Patients with severe URI only occur in toddlers. Interestingly, $60 \%$ of patients with severe URI had complete immunization. Patients with severe URI had parents with moderate $(60 \%)$ and low income (40\%). There were $100 \%$ of patients with severe URI who had acyanotic CHD.

\section{CONFLICT OF INTEREST}

The author stated there is no conflict of interest in this study.

\section{REFERENCES}

1.Abou-Taleb A, Abdelhamid MA and Bahkeet MAM. Clinical Profile of Cyanotic Congenital Heart Disease in Neonatal Intensive Care Unit at Sohag University Hospital, Upper Egypt. Egyptian Journal of Medical Human Genetics. 2017; 18: 47-51.

2.Robbins JM, Onukwube J, Goudie A and Collins RT, 2nd. How Often is Congenital Heart Disease Recognized as a Significant Comorbidity among Hospitalized Adults with Congenital Heart Disease? International Journal of Cardiology. 2017; 235: 42-8.

3.Bhardwaj R, Kandoria A, Marwah R, et al. Prevalence of Congenital Heart Disease in Rural Population of Himachal - A Population-based Study. Indian Heart Journal. 2016; 68: 48-51.

4.Gimenez S, Teixeira ML, Myashiro R, Carmona MJC, Auler Jr JOC snd Malbouisson LMS. Avaliação Pulmonar em Crianças Portadoras de Cardiopatia Congênita Acianótica e Hiperfluxo Pulmonar Através de Tomografia Computadorizada. Revista Brasileira de Anestesiologia. 2009; 59: 545-57.

5.Wilar R and M. Wantania J. Beberapa Faktor yang Berhubungan dengan Episode Infeksi Saluran Pernapasan Akut pada Anak dengan Penyakit Jantung Bawaan. Sari Pediatri. 2016; 8: 154.

6.Chonmaitree T, Revai K, Grady JJ, et al. Viral Upper Respiratory Tract Infection and Otitis Media Complication in Young Children. Clinical Infectious Diseases : An Official Publication of the Infectious Diseases Society of America. 2008; 46: 815-23.

7.Alrafiaah AS, Alqarny MH, Alkubedan HY, Alqueflie S and Omair A. Are the Saudi Parents Aware of Antibiotic Role in Upper Respiratory Tract Infections in Children? Journal of Infection and Public Health. 2017; 10: 579-85.

8.Wardhani AK. Gambaran ISPA pada Anak dengan Penyakit Jantung Bawaan Asianotik di Rumah Sakit PHC Surabaya. Surabaya: Widya Mandala Catholic University, 2016.

9.Syahidi MH, Gayatri D and Bantas K. Faktor-faktor yang Mempengaruhi Kejadian Infeksi Saluran Pernapasan Akut (ISPA) pada Anak Berumur 12-59 Bulan di Puskesmas Kelurahan Tebet Barat, Kecamatan Tebet, Jakarta Selatan, Tahun 2013. Jurnal Epidemiologi Kesehatan Indonesia. 2016; 1: 23-7.

10.Ingersoll MA. Sex Differences Shape the Response to Infectious Diseases. Plos Pathog. 2017; 13: E1006688E.

11.Keman S, Sulistyorini L and Sukamawa AAA. Determinan Sanitasi Rumah dan Sosial Ekonomi Keluarga Terhadap Kejadian ISPA pada Anak Balita Serta Manajemen Penanggulangannya di Puskesmas. Jurnal Kesehatan Lingkungan. 2006.

12.Duppenthaler A, Ammann RA, Gorgievski-Hrisoho M, Pfammatter JP and Aebi C. Low Incidence of Respiratory Syncytial Virus Hospitalisations in Haemodynamically Significant Congenital Heart Disease. Archives of Disease in Childhood. 2004; 89: 961-5.

13.Boyce TG, Mellen BG, Mitchel EF, Jr., Wright PF and Griffin MR. Rates of Hospitalization for Respiratory Syncytial Virus Infection among Children in Medicaid. The Journal of Pediatrics. 2000; 137: 865-70.

14.Brook I. Anaerobic Bacteria In Upper Respiratory Tract and Head and Neck Infections: Microbiology and Treatment. Anaerobe. 2012; 18: 214-20.

15.Cabalka AK. Physiologic Risk Factors for Respiratory Viral Infections and Immunoprophylaxis for Respiratory Syncytial Virus in Young Children with Congenital Heart Disease. The Pediatric Infectious Disease Journal. 2004; 23: S41-5.

16.Nur Ft, Febriani $Y$ and Nugraheni A. Hubungan Antara Status Imunisasi dan Infeksi Saluran Pernafasan Akut (ISPA) pada Balita di Puskesmas Ngoresan Surakarta. Jurnal Placentum. 2017; 5: 1-11.

17.Garten R, Blanton L, Elal AIA, et al. Update: Influenza Activity in the United States During the 2017-18 Season and Composition of the 2018-19 Influenza Vaccine. Morbidity and Mortality Weekly Report (MMWR). Atlanta: Centers for Disease Control and Prevention 2018, P. 634-42.

18.Dowd JB, Zajacova A and Aiello A. Early Origins of Health Disparities: Burden of Infection, Health, and Socioeconomic Status in U.S. Children. Soc Sci Med. 2009; 68: 699-707.

19.Baig SA, Hassan M, Ahmed SM, Moazzam W and Inayat A. A Cross-Sectional Study to Investigate Pneumococcal Vaccination in the Elderly in a Low Income County: Patient Knowledge, Awareness, and Attitudes of Vaccination and Prevalence Rates by Socioeconomic Status. Human Vaccines \& Immunotherapeutics. 2014; 10: 1024-7.

20.Moore KL, Dalley AF and Agur AM. Clinical Oriented Anatomy. 7th Ed. Philadelphia: Lippincott Williams \& Wilkins, 2014. 